\title{
MERANCANG TEKNIK PENILAIAN BERBASIS KELAS: Kasus Guru Fiqih Tsanawiyah
}

\author{
Asis Saefuddin \\ Fakultas Tarbiyah dan Keguruan UIN Sunan Gunung Djati Bandung \\ Jl. A.H. Nasution No. 105 Cibiru Bandung 40614 \\ E-mail: asisbanten@gmail.com
}

\begin{abstract}
ABSTRAK
Sebelumnya, guru-guru fiqih di Madrasah Tsanawiyah masih kesulitan dalam mengukur dengan benar kompetensi dan hasil belajar siswanya. Berarti, validitas hasil penilaian guru yang bersangkutan masih diragukan. Penyebabnya adalah minimnya pengetahuan dan kurang bervariasinya mereka dalam menilai hasil belajar. Guru Fiqih Madrasah Tsanawiyah, rata-rata belum mengenal teknik penilaian berbasis kelas sehingga belum menguasai teknik-teknik dasar penilaian yang dipersyaratkan dalam teknik penilaian berbasis kelas, seperti penilaian produk, portofolio, proyek, performa, sikap dan penilaian pribadi. Tulisan ini bertujuan memperkenalkan teknik penilaian berbasis kelas kemudian mendeskripsikan kompetensi guru fiqih Madrasah Tsanawiyah dalam merancang teknik penilaian berbasis kelas. Penelitian ini menggunakan pendekatan kualitatif-deskriptif. Metode mengumpulkan data dilakukan dengan pengamatan (observasi). Alat pengamatan menggunakan lembar observasi dan berbagai format tes penilaian berbasis kelas. Hasil penelitian menunjukkan bahwa setelah diperkenalkan dengan teknik penilaian berbasis kelas, ternyata, guru fiqih Tsanawiyah rata-rata memiliki tingkat kompetensi yang cukup dalam merancang teknik penilai tersebut.
\end{abstract}

Kata Kunci : Merancang, Teknik, Penilaian, Berbasis kelas

\section{ABSTRACT}

Previously, the teachers of figh at Madrasah Tsanawiyah still have the difficulties in correctly measuring the competence and student learning outcomes. It means, the validity of the result of teacher assessments is still in doubt. It's caused the lack of knowledge and variation in assessing their learning outcomes. The teacher of Madrasah Tsanawiyah on average are not familiar with classroom-based assessment techniques that have not mastered the basic techniques required in the assessment of classroom-based assessment techniques, such as product assessment, portfolio, project, performance, attitude and personal assessment. This paper aims to introduce a class-based assessment techniques and then describe of fiqh teacher competency in designing classroom-based assessment techniques. This research uses qualitative-descriptive method, where instruments for data collection are observation/observation sheets and test. The results of data processing indicates that after receiving the learning materials about classroom assessment techniques, which include product assessment techniques, portfolios, projects, performance, attitude and self-assessment, the competence of fiqh teachers in designing classroom-based assessment techniques is considered at the average level.

Keywords: Planning, Assessment Technique, Class-based 
Asis Saefuddin

\section{PENDAHULUAN}

Salah satu kompetensi pedagogik guru yang dijabarkan dalam lampiran Permendiknas Nomor 16 Tahun 2007 tentang Standar Kualifikasi Akademik dan Kompetensi Guru, dinyatakan bahwa guru mempunyai tugas menyelenggarakan penilaian terhadap proses dan hasil belajar. Berdasarkan Permendiknas tersebut, guru diharapkan mampu melaksanakan penilaian pembelajaran untuk mengukur kemampuan dan daya serap peserta didik dan mengukur tingkat keberhasilan program pembelajaran yang didesainnya.

Dalam Peraturan Pemerintah Republik Indonesia Nomor 19 tentang Standar Nasional Pendidikan Pasal 19 ayat (3) dijelaskan, bahwa setiap satuan pendidikan diharuskan melakukan perencanaan proses pembelajaran, pelaksanaan proses pembelajaran, penilaian hasil pembelajaran dan pengawasan terhadap proses pembelajaran agar seluruh rangkaian pelaksanaan proses pembelajaran berlangsung efektif dan efisien. Dalam pasal 22 ayat (1) dijelaskan pula bahwa penilaian hasil pembelajaran pada jenjang pendidikan dasar dan menengah diharapkan dapat menggunakan berbagai teknik penilaian sesuai dengan kompetensi dasar yang harus dikuasai oleh siswa.

Berdasarkan kebijakan di atas dapat dipahami bahwa 1) persoalan penilaian hasil belajar bukan hanya tanggung jawab guru mata pelajaran tetapi juga merupakan tanggung jawab bersama seluruh unsur satuan pendidikan; 2) guru sebagai ujung tombak penyelenggaraan pendidikan hendaknya secara bervariasi mampu menggunakan berbagai teknik evaluasi yang sesuai dengan karakteristik mata pelajaran dan karakteristik siswa.

Dalam Kurikulum Tingkat Satuan Pendidikan (KTSP) tersirat bahwa seorang guru, dalam pembelajaran di kelas, secara terintegrasi, hendaknya mampu melaksanakan penilaian berbasis kelas. Berbeda dengan model penilaian konvensional yang mengandaikan bahwa guru sebelumnya tidak perlu mengetahui secara jelas hal yang hendak diukur dan lebih banyak mengukur aspek kognitifnya saja, teknik penilaian berbasis kelas lebih komprehensif. Penilaian berbasis kelas melingkupi penilaian unjuk kerja, produk, portofolio dan penilaian sikap. Penilaian berbasis kelas menghendaki guru, kecuali mampu merumuskan penilaian secara tepat juga dapat mengukur keberhasilan belajar peserta didik sesuai dengan aspek kompetensi yang telah dirumuskan dalam kurikulum. Dalam aspek yang lebih luas, guru dapat menjawab tantangan dunia pendidikan yang mengarah pada pencapaian manusia yang berkualitas.

Pada umumnya, guru-guru Mata Pelajaran Fiqih di Madrasah Tsanawiyah mempunyai kesulitan dalam menentukan teknik penilaian dan instrumen penilaian pembelajaran fiqih. Salah satu penyebab kesulitan tersebut adalah guru kurang memiliki wawasan, pengetahuan dan penguasaan terhadap berbagai teknik penilaian yang banyak dan bervariasi itu. Akibatnya, guru terbatas dalam memilih alat ukur yang tepat sesuai dengan karakter mata pelajaran dan karakter mengukur kompetensi yang hendak diukur dari peserta didik. Kelemahan lain adalah guru kurang memperhatikan ketercapaian kompetensi dasar dalam 
melaksanakan proses pembelajaran dan evaluasi pembelajaran. Masih banyak guru yang mengajar hanya berorientasi pada materi atau bahan ajar, sehingga guru sering melakukan kesalahan dalam mengukur serta menilai hasil belajar dan kompetensi peserta didik.

Memandang berbagai kenyataan di atas, peneliti bermaksud membekali kemampuan Guru Mata Pelajaran Fiqih Madrasah Tsanawiyah dalam merancang teknik penilaian pembelajaran berbasis kelas. Pembekalan dilakukan melalui pendidikan dan latihan (diklat) Penilaian Berbasis Kelas Diklat Guru Fiqih Madrasah Tsanawiyah yang diselenggarakan Balai Diklat. Kemenag. Provinsi Jawa Barat. Di samping melakukan pembekalan, penulis juga melakukan penelitian tentang tingkat kompetensi/kemampuan guru dalam merancang berbagai prasyarat penilaian berbasis kelas seperti penilaian unjuk kerja, penilaian produk, penilaian proyek, penilaian portofolio, dan penilaian sikap.

\section{PEMBAHASAN}

\section{Kompetensi Guru Madrasah Tsanawiyah}

Kompetensi adalah kinerja rasional (rational performance) yang memuaskan berdasarkan persyaratan tertentu dalam rangka mencapai tujuan dan kondisi yang diharapkan. Dalam Undang-undang Guru dan Dosen Nomor 14 Tahun 2005 disebutkan bahwa kompetensi adalah seperangkat pengetahuan, keterampilan, dan perilaku yang harus dimiliki, dihayati, dan dikuasai oleh guru dan dosen dalam melaksanakan tugasnya secara profesional.

Kompetensi identik dengan ability. Ability adalah kapasitas atau kewenangan dikarenakan seorang individu memiliki kemampuan untuk mengerjakan berbagai tugas dalam suatu pekerjaan. Pada dasarnya, kemampuan individu tersebut dibentuk oleh dua faktor, yaitu faktor kemampuan intelektual dan kemampuan fisik. Kemampuan intelektual adalah kemampuan yang diperlukan untuk melakukan kegiatan mental sedangkan kemampuan fisik adalah kemampuan yang diperlukan untuk melakukan tugas-tugas yang menuntut stamina, kecekatan, kekuatan, dan kelihaian.

Berdasarkan undang-undang, guru sebagai profesional sekurangkurangnya harus menguasai dengan baik 4 (empat) kompetensi. Empat kompetensi tersebut mencakup; a) kompetensi substansi, yakni penguasaan materi yang berkaitan dengan mata pelajaran yang dibinanya, sesuai dengan kurikulum yang berlaku, b) kompetensi metodologi pedagogik, yakni penguasaan didaktik-metodik yang berhubungan secara khusus dengan mata pelajaran yang diampunya, c) kompetensi evaluatif, yakni penguasaan berbagai teknik penilaian dengan baik, dan d) pemahaman penghayatan dan pengamalan nilai-nilai dari kode etik profesi keguruan.

Uraian undang-undang di atas menunjukkan bahwa salah satu tugas profesional guru dalam kegiatan pembelajaran adalah guru dituntut untuk melakukan penilaian kelas secara efektif dan efisien. Penilaian kelas yang efektif dan efisien merupakan rangkaian pengambilan keputusan tentang pencapaian 
kompetensi atau hasil belajar seluruh peserta didik dalam satu kelas atau rombongan belajar. Dalam rangka menyusun keputusan pencapaian kemampuan siswa yang sahih, guru memerlukan sejumlah data sebagai dasar bagi pengambilan keputusan. Dalam arti ini, penilaian berbasis kelas pada dasarnya merupakan suatu kegiatan pengumpulan informasi sebanyak mungkin yang berhubungan dengan perencanaan, proses dan produk (hasil) belajar siswa. Keseluruhan kegiatan pengumpulan data ini dilakukan guru mata pelajaran yang bersangkutan semata-mata agar dapat digunakan sebagai alat untuk "mengukur apa yang hendak diukur" dari siswa. Berarti, penguasaan teknik evaluasi yang baik mutlak diperlukan guru. Guru harus melakukan penilaian dengan benar terhadap proses belajar mengajar. Pelaksanaan penilaian yang benar akan menghasilkan data dan informasi yang akurat tentang tingkat pencapaian hasil serta tentang tingkat kefektifitasan dan efesiensi proses pembelajaran.

Dalam konteks hukum, yakni berdasarkan undang-undang, guru Madrasah Tsanawiyah, tanpa kecuali harus memiliki kemampuan profesional yang sama sebagaimana yang dipersyaratkan kepada guru-guru pada umumnya. Berarti, guru Madrasah Tsanawiyah harus menguasai keempat kompetensi guru termasuk kompetensi menyelenggarakan penilaian yang baik.

Peraturan Menteri Pendidikan Nasional No. 16 Tahun 2007 tentang Standar Kualifikasi Akademik dan Kompetensi Guru Madrasah Tsanawiyah dinyatakan bahwa salah satu kompetensi pedagogik guru MTs adalah menyelenggarakan penilaian, baik proses maupun hasil belajar. Prinsipnya, dalam kegiatan penilain tersebut menuntut sejumlah kemampuan, diantaranya: 1) guru MTs memahami dasar-dasar penilaian kelas yang meliputi penilain proses dan hasil belajar sesuai dengan karakteristik mata pelajaran yang diampunya, 2) guru MTs mampu menentukan aspek-aspek pedagogis yang berhubungan dengan proses dan hasil belajar yang dipandang penting untuk dinilai sesuai dengan karakteristik mata pelajaran yang diampunya, 3)guru MTs dapat menentukan prosedur penilaian baik proses maupun hasil belajar, 4) guru MTs terampil dalam mengembangkan berbagai instrumen penilaian yang berhubungan dengan proses dan hasil belajar, 5) guru MTs, secara berkeseninambungan, piawai dalam mengadministrasikan berbagai teknik penilaian, menggunakan beracam-macam instrumen, menganalisis dan memaknai hasil penilaian, yang berhubungan dengan proses maupun hasil belajar, demi tercapainya berbagai tujuan pembelajaran.

Guru Mata Pelajaran Fiqih adalah salah satu guru bidang studi yang berada pada satuan pendidikan Madrasah Tsanawiyah. Berdasarkan undang-undang, dalam mengembangkan penilaian pembelajaran, guru fiqih hendaknya memperhatikan berbagai hal yang terkait dengan kemampuan penilaian, baik yang bersifat internal maupun eksternal. Secara eksternal, guru fiqih hendaknya dapat merespons perubahan-perubahan yang terjadi "di luar sekolah". Perubahan yang sangat cepat terjadi pada hampir semua aspek kehidupan, terutama pada bidang informasi, teknologi dan sains. Perkembangan sains dan 
teknologi berdampak pada berkembangnya paradigma baru dalam kehidupan berbangsa, bernegara, dan bermasyarakat, yakni meluasnya isu-isu globalisasi, demokrasi, gender, dan multikulturalisme. Isu-isu eksternal pendidikan berpengaruh pada kondisi internal pendidikan. Isu global menuntut secara internal pengembangan kurikulum Fiqih Madrasah Tsanawiyah (MTs) yang lebih manusiawi, terbuka untuk diperdebatkan dan mampu merespons perkembangan zaman. Implementasi kurikulumnya juga menuntut pelaksanaan pembelajaran yang efektif dan efisien. Kurikulum nasional memiliki ciri-ciri, antara lain; 1) lebih menitikberatkan pada pencapaian target kompetensi (attainment targets) dan pada penguasaan materi, 2) lebih mengakomodasikan keragaman kebutuhan dan sumber daya pendidikan yang tersedia, dan 3) memberikan kebebasan yang lebih luas kepada pelaksana pendidikan di lapangan untuk mengembangkan dan melaksanakan program pembelajaran sesuai dengan kebutuhan. Dengan demikian, guru fiqih sebagai bagian dari guru Madrasah Tsanawiyah hendaknya memiliki sejumlah kompetensi profesional yang tidak jauh berbeda dengan guru lain pada umumnya, yakni memiliki seperangkat kemampuan yang meliputi pengetahuan, keterampilan, dan perilaku yang harus dimiliki, dihayati, dan dikuasai oleh guru Fiqih Madrasah Tsanawiyah dalam melaksanakan tugas profesional keguruannnya baik secara fisik maupun intelektual.

\section{Penilaian Berbasis Kelas}

The collection of information is fundamental to evaluation (Worthen and Sanders, 1987: 298). Filosofi inilah yang menginspirasi digagasnya teknik penilaian berbasis kelas. Muslich (2009:91) mengadopsi pandangan ini dengan mengatakan bahwa penilaian berbasis kelas pada dasarnya adalah suatu kegiatan mengumpulkan informasi yang berhubungan dengan proses dan hasil belajar siswa. Hanya saja, upaya mengumpulkan informasi yang dilakukan guru ini lebih lanjut ditujukan dalam rangka "mengukur apa yang hendak diukur" dari siswa. Muslich (2009:91) menambahkan bahwa penilaian dalam Kurikulum Berbasis Kompetensi (KBK) menganut prinsip penilaian berkelanjutan dan komprehensif guna mendukung upaya memandirikan siswa dalam belajar, bekerja sama, dan menilai diri sendiri. Dengan demikian, penilaian berbasis kelas pada dasarnya menekankan pada kegiatan guru dalam mengumpulkan fakta dan data sebanyak mungkin tentang keseluruhan proses pembelajaran pada suatu kelas yang selanjutnya digunakan sebagai dasar pengambilan keputusan tentang pencapaian kompetensi atau hasil belajar peserta didik. Dalam arti ini, data dan informasi merupakan ciri dan kunci yang dapat diandalkan sebagai dasar pengambilan keputusan. Ciri lain bahwa penilaian ini disebut penilaian berbasis kelas, karena penilaian ini merupakan kegiatan penilaian yang dilaksanakan secara terpadu dalam konteks kegiatan pembelajaran dalam satu rombongan belajar. Data yang diperoleh guru selama pembelajaran berlangsung dikumpulkan dan disaring melalui prosedur dan alat penilaian yang sesuai dengan kompetensi atau indikator yang akan dinilai. Dari proses ini, kemudian diperoleh potret/profil 
kemampuan peserta didik dalam mencapai sejumlah standar kompetensi dan kompetensi dasar yang dirumuskan dalam Kurikulum Tingkat Satuan Pendidikan masing-masing.

Keseluruhan proses penilaian berbasis kelas dilakukan melalui langkahlangkah; 1) perencanaan, 2) penyusunan alat penilaian, 3) pengumpulan informasi melalui sejumlah bukti yang menunjukkan pencapaian hasil belajar peserta didik, 4) pengolahan, dan 5) penggunaan informasi tentang hasil belajar peserta didik sebagai dasar pengambilan keputusan.

Dalam memenuhi keperluan penilaian berbasis kelas, ada beberapa teknik mengumpulkan informasi, fakta dan data yang harus dikuasai oleh guru bidang studi, guna mengumpulkan informasi tentang kemajuan belajar siswa, baik yang berhubungan dengan proses belajar maupun hasil belajar. Berbagai teknik/cara mengumpulkan informasi, fakta dan data tersebut yaitu; 1) penilaian unjuk kerja (performance), 2) penilaian sikap, 3) penilaian tertulis (paper and pencil test), 4) penilaian proyek, 5) penilaian produk, 6) penilaian melalui kumpulan hasil kerja/karya peserta didik (portfolio), dan 7) penilaian diri. Ketujuh teknik pengumpulan data ini masih terkesan sebagai "penilaian", namun "penilaian" yang dimaksud bukan semata-mata bersifat normatif dan memvonis "baik" atau "buruk ". "Penilaian" dalam konteks ini lebih mendeskripsikan hasil belajar siswa sehingga secara mandiri, siswa dapat mengambil sikap atas hasil belajarnya sendiri tanpa intervensi berlebihan dari guru. Dasar berpikirnya adalah agar siswa mampu menunjukkan kesadarannya sendiri, eksistensi dirinya sendiri, tidak tertekan sehingga dampak perbaikannya asli dan murni dari dalam. Meskipun begitu, teknik pengumpulan informasi, fakta dan data di atas, tetap memperhatikan prinsip kemajuan (progresivisme) belajar siswa berdasarkan standar kompetensi dan kompetensi dasar yang dikembangkan dalam indikator-indikator yang harus dicapai oleh peserta didik. Indikator-indikator pencapaian hasil belajar dapat berupa domain kognitif, afektif, maupun psikomotor. Berdasarkan penjelasan di atas, tujuh teknik "penilaian", pengumpulan informasi, fakta dan data yang digunakan oleh guru, sedemikian rupa harus mencerminkan tiga domain (kognitif, afektif dan psikomotor) di atas.

Hal lain yang hendaknya diperhatikan oleh guru dalam menerapkan penilaian berbasis kelas yaitu; 1) terbangunnya suasana yang rileks dan menyenangkan namun bermakna. Maksud bermakna adalah memungkinkan semua peserta didik menunjukkan hal-hal yang dipahami dan mampu dikerjakannya; 2) Hasil belajar seorang peserta didik dalam periode waktu tertentu dapat dibandingkan dengan hasil sebelumnya yang dimiliki oleh peserta didik yang bersangkutan tetapi tidak dianjurkan untuk dibandingkan dengan peserta didik lainnya; 3) upayakan peserta didik tidak merasa dihakimi oleh guru. Peserta didik justru merasa dibantu untuk mencapai kompetensi dan/atau indikator yang diharapkan berdasarkan karakteristik bidang studi masing-masing. 


\section{Penggunaan Ragam Penilaian sebagai Basis Pengumpulan Informasi}

1. Penilaian Unjuk Kerja

Penilaian unjuk kerja merupakan penilaian yang dilakukan dengan cara mengamati kegiatan peserta didik dalam melakukan suatu aktivitas pembelajaran. Penilaian ini cocok digunakan untuk menilai ketercapaian kompetensi yang menuntut peserta didik melakukan tugas tertentu seperti: praktek di laboratorium, praktik sholat, praktik olahraga, bermain peran, memainkan alat musik, bernyanyi, membaca puisi/deklamasi. Dalam konteks mata pelajaran fiqih misalnya mengamati dan menilai kemampuan siswa mempraktikkan tata cara wudlu.

Penilaian unjuk kerja perlu mempertimbangkan hal-hal berikut, yaitu: 1) langkah-langkah kinerja yang diharapkan dilakukan peserta didik untuk menunjukkan kinerja suatu kompetensi, 2) kelengkapan dan ketepatan aspek yang akan dinilai dalam kinerja tersebut, dan 3) kemampuan-kemampuan khusus yang diperlukan untuk menyelesaikan tugas. Kemampuan yang akan dinilai dianjurkan tidak terlalu banyak, agar seluruh kemampuan dapat diamati. Kemampuan yang akan dinilai hendaknya diurutkan berdasarkan urutan pengamatan.

Pelaksanaan pengamatan unjuk kerja dapat dilakukan melalui tindakan pengamatan unjuk kerja dalam berbagai konteks, situasi dan kondisi, yang penting dapat menetapkan tingkat pencapaian kemampuan tertentu dari siswa. Akan tetapi gambaran kemampuan peserta didik diharapkan dapat terekam lebih utuh. Untuk mengamati unjuk kerja peserta didik, dapat menggunakan daftar cek (ya-tidak) dan skala.

Penggunaan daftar cek terhadap peserta didik mengandung penilaian ketika sejumlah kriteria penguasaan kompetensi tertentu dapat diamati oleh observer. Jika tidak dapat diamati, peserta didik tidak memperoleh nilai. Kelemahan cara ini adalah (penilai) pengamat hanya mempunyai dua pilihan objektif, misalnya; "ya" atau "tidak", "benar" atau "salah", "dapat diamati" atau "tidak dapat diamati", sehingga kurang memperhitungkan nilai tengah. Daftar cek lebih praktis digunakan untuk mengamati subjek dalam jumlah besar. Berikut adalah contoh daftar cek tentang penilaian/pengamatan Mata Pelajaran Fiqih pokok bahasan Praktik Wudlu.

Contoh: Daftar Cek Penilaian Praktik Wudlu

\begin{tabular}{|l|l|l|l|}
\hline No & \multicolumn{1}{|c|}{ Aspek Yang Dinilai } & Baik & Tidak baik \\
\hline 1. & Pengucapan niat & & \\
\hline 2. & Tertib wudhu & & \\
\hline $3 . \quad$ Hafalan Bacaan Doa & & \\
\hline Skor yang dicapai & & \\
\hline \multicolumn{2}{|l|}{ Skor maksimum } & & \\
\hline
\end{tabular}


Penilaian unjuk kerja yang menggunakan skala memungkinkan penilai/pengamat memberi nilai tengah terhadap penguasaan kompetensi tertentu. Skala, secara kontinum memberikan nilai, sebab pilihan kategori nilai yang disajikan lebih dari dua. Rentang skala penilaian ini dapat mulai dari "tidak sempurna" sampai ke "sangat sempurna", misalnya: 1 = tidak kompeten, $2=$ cukup kompeten, 3 = kompeten, dan 4 = sangat kompeten.

Contoh Format Penilaian/Pengamatan Skala dalam Praktik Shalat

Nama:

Kelas:

\begin{tabular}{|c|l|c|c|c|c|}
\hline \multirow{2}{*}{ No } & \multicolumn{1}{|c|}{ Aspek yang dinilai } & \multicolumn{4}{|c|}{ Nilai } \\
\cline { 3 - 6 } & & 1 & 2 & 3 & 4 \\
\hline 1 & Pengucapan niat & & & & \\
\hline 2 & Tertib shalat & & & & \\
\hline 3 & Hafalan bacaan shalat & & & & \\
\hline Jumlah & & & & \\
\hline \multicolumn{2}{|l|}{ Skor maksimum } & & & & \\
\hline
\end{tabular}

Keterangan:

$$
\begin{aligned}
& 1=\text { tidak kompeten } \\
& 2=\text { cukup kompeten } \\
& 3=\text { kompeten } \\
& 4=\text { sangat kompeten }
\end{aligned}
$$

\section{Penilaian sikap}

Penilaian sikap hendaknya mencakup tiga domain/komponen pembelajaran, yakni: afektif, kognitif, dan konatif. Komponen afektif adalah perasaan yang dimiliki oleh seseorang atau penilaiannya terhadap sesuatu objek. Komponen kognitif adalah kepercayaan atau keyakinan seseorang mengenai objek. Adapun komponen konatif adalah kecenderungan untuk berperilaku atau berbuat dengan cara-cara tertentu berkenaan dengan kehadiran objek sikap.

Secara umum, objek sikap yang perlu dinilai dalam proses pembelajaran berbagai mata pelajaran yaitu; 1) sikap terhadap materi pelajaran. Peserta didik perlu memiliki sikap "positif" terhadap mata pelajaran. Dengan sikap "positif", di dalam diri peserta didik akan tumbuh dan berkembang minat belajar. Dengan demikian, peserta didik akan lebih mudah diberi motivasi, dan akan lebih mudah menyerap materi pelajaran yang diajarkan; 2) sikap terhadap guru/pengajar. Peserta didik perlu memiliki sikap "positif" terhadap guru. Peserta didik yang tidak memiliki sikap "positif" terhadap guru akan cenderung mengabaikan halhal yang diajarkan oleh gurunya. Dengan demikian, peserta didik yang memiliki sikap "negatif" terhadap guru/pengajar akan sukar menyerap materi pelajaran yang diajarkan oleh guru tersebut 
Penilaian sikap dapat dilakukan dengan beberapa cara atau teknik. Teknikteknik tersebut antara lain: observasi perilaku, pertanyaan langsung, dan laporan pribadi. Observasi perilaku merupakan tindakan seseorang pada umumnya yang menunjukkan kecenderungan sikap seseorang terhadap suatu hal. Misalnya, orang yang biasa minum kopi dapat dipahami sebagai kecenderungannya yang senang kepada kopi. Dalam konteks ini, guru dapat mengamati setiap gerak-gerik peserta didik di dalam kelas. Hasil observasi dapat dijadikan sebagai umpan balik dalam merancang tindakan pembinaan berikutnya. Observasi perilaku di sekolah dapat dilakukan dengan menggunakan buku catatan khusus tentang kejadiankejadian yang berhubungan dengan peserta didik selama di kelas. Di dalam buku catatan tersebut terdapat kolom-kolom kejadian. Kolom kejadian diisi dengan kejadian "positif' maupun "negatif'. Catatan dalam lembaran buku tersebut, selain bermanfaat untuk merekam dan menilai perilaku peserta didik, juga sangat bermanfaat dalam menggambarkan sikap peserta didik serta dapat menjadi bahan penilaian tentang perkembangan peserta didik secara keseluruhan. Dalam observasi perilaku dapat juga digunakan daftar cek yang memuat perilakuperilaku tertentu yang diharapkan muncul dari peserta didik pada umumnya. Berikut adalah contoh format penilaian sikap dalam praktik wudlu.

Contoh Format Penilaian Sikap dalam Praktik Wudlu

\begin{tabular}{|c|c|c|c|c|c|c|c|}
\hline \multirow{2}{*}{ No } & \multirow{2}{*}{ Nama } & \multicolumn{4}{|c|}{ Perilaku } & \multirow[t]{2}{*}{ Nilai } & \multirow[t]{2}{*}{ Ket } \\
\hline & & A & B & $\mathrm{C}$ & $\mathrm{D}$ & & \\
\hline 1 & Ruri & & & & & & \\
\hline 2 & Tono & & & & & & \\
\hline 3 & $\ldots$ & & & & & & \\
\hline
\end{tabular}

Keterangan :
A : penuh perhatian
$\mathrm{B}$ : bekerja sistematis
C : berinisiatif
$\mathrm{D}$ : mandiri

Catatan:

a. Kolom perilaku diisi dengan angka yang sesuai dengan kriteria berikut;

$1=$ sangat kurang

$2=$ kurang

$3=$ sedang

$4=$ baik

5 = amat baik

b. Nilai merupakan jumlah dari skor-skor tiap indikator perilaku

c. Keterangan diisi dengan kriteria berikut;

1. Nilai $18-20$ berarti amat baik

2. Nilai $14-17$ berarti baik 
3. Nilai $10-13$ berarti sedang

4. Nilai 6-9 berarti kurang

5. Nilai 0-5 berarti sangat kurang

3. Penilaian Tertulis

Penilaian tertulis adalah penilaian guru terhadap peserta didik dengan cara mengajukan butir-butir pertanyaan atau soal dalam bentuk tertulis. Jawaban yang diberikan siswa pun dilakukan secara tertulis pula (Haryati, 2007: 52). Penilaian tertulis adalah penilaian yang paling banyak digunakan oleh guru. Penilaian tertulis ada dua jenis yaitu penilaian objektif dan penilaian subjektif. Penilaian objektif biasanya berbentuk tes pilihan ganda. Dalam tes pilihan ganda kunci jawaban sudah tersedia dan siswa tinggal memilihnya. Berikut adalah contoh tes objektif pilihan ganda:

4. Ada berapakah syarat-syarat wudlu?
a. 4
c. 6
b. 5
d. 7

Lembar Jawaban

No.

1. $\mathrm{B}$

2. $\mathrm{C}$

3. A

4. C

5. C

6.

Meskipun penilain tertulis dianggap biasa dilakukan oleh guru, namun demi tercapainya penilaian yang baik maka guru perlu memperhatikan hal-hal berikut, yaitu; 1) kelas hendaknya dibuat kondusif. Sedemikian rupa kelas dibuat menjadi nyaman dan tidak gaduh agar siswa dapat berkonsentrasi; 2) tempat duduk ditata sebaik mungkin sehingga kecurangan-kecurangan siswa dapat diminimalisir; 3) pencahayaan di kelas harus diatur. Cahaya yang masuk ke kelas diupayakan tidak terlalu terang sehingga tidak membuat silau mata siswa juga tidak boleh gelap atau remang-remang; 4) dalam mengawasi siswa, guru bertindak wajar, jangan terlalu over, 5) guru hendaknya memperhitungkan waktu yang disediakan untuk tes. Ketika waktu sudah habis, siswa diperingatkan agar sesegera mungkin mengakhiri tes. Dalam penilaian tertulis, aspek waktu menjadi perhatian penting sebab berhubungan dengan tingkat kecepatan siswa menjawab soal selain juga tingkat ketepatan jawaban (Haryati, 2007: 53).

4. Penilaian Proyek

Penilaian proyek merupakan kegiatan penilaian terhadap suatu tugas yang harus diselesaikan dalam periode/waktu tertentu. Tugas tersebut berupa suatu 
investigasi sejak dari perencanaan, pengumpulan, pengorganisasian, pengolahan dan penyajian data. Penilaian proyek digunakan untuk mengetahui pemahaman, kemampuan mengaplikasikan, kemampuan meneliti dan kemampuan menginformasikan data dari peserta didik yang sesuai dengan karakteristik mata pelajaran secara jelas dan tepat.

Dalam menyusun penilaian proyek, setidaknya ada 3 (tiga) hal yang perlu dipertimbangkan yaitu: 1) pengelolaan, maksudnya, guru memperhatikan kemampuan siswa dalam memilih topik, mencari informasi, menggunakan waktu hingga melaporkan hasil belajar peserta didik; 2) relevansi, yaitu kesesuaian halhal yang dikerjakan siswa terhadap karakteristik mata pelajaran, dengan mempertimbangkan tahap pengetahuan, pemahaman dan keterampilan siswa dalam pembelajaran; 3) keaslian, yaitu penjaminan kualitas proyek peserta didik sebagai hasil karyanya sendiri, dengan mempertimbangkan tingkat kontribusi guru yang dibuktikan dengan kelengkapan petunjuk dan dukungan terhadap proyek yang dikerjakan peserta didik.

Penilaian proyek dilakukan mulai dari perencanaan, proses pengerjaan, sampai hasil akhir proyek. Untuk itu, guru perlu menetapkan hal-hal atau tahapan yang perlu dinilai, seperti penyusunan desain, pengumpulan data, analisis data, dan penyiapan laporan tertulis. Laporan tugas atau hasil penelitian dapat disajikan dalam bentuk poster. Pelaksanaan penilaian dapat menggunakan alat/instrumen penilaian berupa daftar cek dan/atau skala penilaian.

Contoh kegiatan peserta didik dalam penilaian proyek adalah membuat tugas karya tulis. Maka format penilaian proyek dapat dibuat seperti contoh di bawah ini:

Contoh Format Penilaian Proyek (Karya Tulis)

\begin{tabular}{|l|c|c|c|}
\hline \multicolumn{2}{|c|}{ Aspek yang dinilai } & \multicolumn{2}{|c|}{ Skor } \\
\cline { 2 - 4 } $\begin{array}{l}\text { Keterampilan } \\
\text { 1. Merencanakan penelitian }\end{array}$ & & & \\
\hline 2. Aktivitas pengamatan & & & \\
\hline 3. Menggambar hasil pengamatan & & & \\
\hline 4. Pembuatan catatan hasil pengamatan & & & \\
\hline 5. Pelaporan & & & \\
\hline Sikap & & & \\
\hline 1. Mampu bekerjasama & & & \\
\hline 2. Sistematis dalam mengerjakan tugas & & & \\
\hline 3. Mengerjakan tugas dengan serius & & & \\
\hline
\end{tabular}

Keterangan: B: skor 5; C: skor 3; K: skor 1

5. Penilaian Produk

Penilaian produk adalah penilaian terhadap proses pembuatan dan kualitas suatu produk. Penilaian produk meliputi penilaian kemampuan peserta didik membuat produk-produk hasil pembelajaran. Contoh penilaian produk dalam 
pembelajaran fiqih diantaranya hasil karya siswa berupa poster tata cara wudlu, dan hasil diskusi yang dipajang di depan kelas.

Pengembangan produk meliputi 3 (tiga) tahap dan setiap tahap perlu diadakan penilaian yaitu: 1) tahap persiapan, meliputi: penilaian kemampuan peserta didik dalam merencanakan, menggali, dan mengembangkan gagasan, serta mendesain produk, 2) tahap pembuatan produk (proses), meliputi: penilaian kemampuan peserta didik dalam menyeleksi, menggunakan bahan, alat, dan teknik membuat produk. 3) tahap penilaian produk, meliputi: penilaian kualitas produk yang dihasilkan peserta didik sesuai dengan kriteria yang ditetapkan.

Contoh Format Penilaian Produk

\begin{tabular}{|c|c|c|c|c|c|c|c|}
\hline \multirow{2}{*}{ No } & \multirow{2}{*}{ Nama } & \multicolumn{4}{|c|}{ Aspek yang dinilai } & \multirow{2}{*}{ Skor } & \multirow{2}{*}{ Nilai } \\
\hline & & $\mathrm{A}$ & $\mathrm{B}$ & $\mathrm{C}$ & I & & \\
\hline 1 & & & & & & & \\
\hline 2 & & & & & & & \\
\hline 3 & & & & & & & \\
\hline
\end{tabular}

Keterangan:

$$
\begin{aligned}
& A=\text { komposisi } \\
& B=\text { kerapihan } \\
& C=\text { kebenaran konsep } \\
& D=\text { kelengkapan keterangan }
\end{aligned}
$$

\section{Penilaian Portofolio}

Penilaian portofolio merupakan penilaian berkelanjutan yang didasarkan pada kumpulan informasi yang menunjukkan perkembangan kemampuan peserta didik dalam satu periode tertentu. Informasi tersebut berupa karya peserta didik dari proses pembelajaran yang dianggap terbaik oleh peserta didik.

Penilaian portofolio pada dasarnya menilai karya-karya siswa secara individu pada satu periode untuk suatu mata pelajaran. Akhir suatu priode hasil karya tersebut, dikumpulkan dan dinilai oleh guru bersama-sama dengan peserta didik. Berdasarkan informasi tersebut, guru dan peserta didik sendiri dapat menilai perkembangan kemampuan peserta didik dan terus melakukan perbaikan. Dengan demikian, portofolio dapat memperlihatkan perkembangan kemajuan belajar peserta didik melalui karyanya, antara lain: karangan, puisi, surat, komposisi, dan musik.

Hal-hal yang perlu diperhatikan dan dijadikan pedoman dalam penggunaan penilaian portofolio di sekolah, antara lain:

a. pastikan bahwa karya siswa adalah benar-benar karya peserta didik itu sendiri. Guru dalam hal ini melakukan penelitian atas hasil karya peserta didik yang dijadikan sebagai bahan penilaian portofolio agar karya tersebut betul-betul merupakan hasil karya yang dibuat oleh 
peserta didik itu sendiri atau bukan plagiasi;

b. terjalin rasa saling percaya antara guru dan peserta didik. Dalam proses penilaian guru dan peserta didik harus memiliki rasa saling percaya, saling memerlukan dan saling membantu sehingga terjadi proses pembelajaran yang berlangsung dengan akrab dan bermakna;

c. membangun kerahasiaan bersama antara guru dengan peserta didik. Kerahasiaan hasil pengumpulan informasi perkembangan peserta didik perlu dijaga dengan baik dan tidak disampaikan kepada pihak-pihak yang tidak berkepentingan sehingga memberi dampak negatif terhadap proses pembelajaran;

d. menjadikan pembelajaran sebagai milik bersama (joint ownership) antara peserta didik dan guru. Guru dan peserta didik perlu mempunyai anggapan yang sama bahwa berkas portofolio adalah milik dan "hasil kerja" bersama, sehingga peserta didik akan merasa memiliki karya yang dikumpulkan dan akhirnya akan berupaya terus meningkatkan kemampuannya.

e. bangun kepuasan di antara guru dan peserta didik. Hasil kerja portofolio sebaiknya berisi keterangan dan atau bukti yang memberikan dorongan kebanggaan bagi peserta didik agar mereka lebih meningkatkan diri.

f. ciptakan kesesuaian dan kejujuran. Hasil kerja yang dikumpulkan adalah hasil kerja yang sesuai dengan kompetensi yang tercantum dalam kurikulum.

g. melingkupi penilaian proses dan hasil. Penilaian portofolio menerapkan prinsip penilaian proses dan hasil. Proses belajar yang dinilai misalnya diperoleh dari catatan guru tentang kinerja dan karya peserta didik.

h. membentuk kesatuan antara penilaian dengan pembelajaran. Penilaian portofolio merupakan hal yang tak terpisahkan dari proses pembelajaran. Manfaat utama penilaian ini sebagai alat mendiagnosis yang sangat berarti bagi guru dalam rangka melihat kelebihan dan kekurangan peserta didik.

\section{Penilaian Diri}

Penilaian diri adalah suatu teknik penilaian di mana peserta didik diminta untuk menilai dirinya sendiri berkaitan dengan status, proses dan tingkat pencapaian kompetensi yang dipelajarinya. Teknik penilaian diri dapat digunakan untuk mengukur kompetensi kognitif, afektif dan psikomotor.

Penilaian diri yang digunakan untuk mengukur kompetensi kognitif di kelas, misalnya, peserta didik diminta untuk menilai penguasaan pengetahuan dan keterampilan berpikirnya sebagai hasil belajar dari suatu mata pelajaran tertentu. Penilaian dirinya didasarkan atas kriteria atau acuan yang telah disiapkan. 
Contoh penilaian diri untuk mengukur kompetensi afektif peserta didik, dapat berupa perintah agar siswa membuat tulisan yang memuat curahan perasaannya terhadap suatu objek tertentu. Peserta didik kemudian diminta untuk melakukan penilaian berdasarkan kriteria atau acuan yang telah disiapkan.

Penilaian diri yang berkaitan dengan penilaian kompetensi psikomotorik, misalnya, peserta didik dapat diminta untuk menilai kecakapan atau keterampilan yang telah dikuasainya berdasarkan kriteria atau acuan yang telah disiapkan. Penggunaan teknik ini dapat memberi dampak positif terhadap perkembangan kepribadian seseorang. Keuntungan penggunaan penilaian diri di kelas antara lain; pertama, dapat menumbuhkan rasa percaya diri peserta didik, karena mereka diberi kepercayaan untuk menilai dirinya sendiri. Dalam konteks ini, peserta didik belajar menyadari kekuatan dan kelemahan dirinya, karena ketika mereka melakukan penilaian, mereka harus melakukan introspeksi terhadap kekuatan dan kelemahan yang dimilikinya. Kedua, guru dapat mendorong, membiasakan, dan melatih peserta didik untuk berbuat jujur, karena mereka dituntut untuk jujur dan objektif dalam melakukan penilaian.

Contoh Format Penilaian Diri:

$\begin{array}{ll}\text { Mata Pelajaran } & \text { : Fiqih } \\ \text { Kelas / Semester } & \text { : VII } \\ \text { Standar Kompetensi } & : 4 . \\ \text { Kompetensi Dasar } & : 4.1 \\ \text { Aspek } & : \text { Penerapan }\end{array}$

Petunjuk :

Isilah tabel di bawah ini dengan tanda ceklis $(\checkmark)$ pada kolom yang sesuai dengan pernyataan sikapmu terhadap pernyataan pada kolom sebelumnya!

\begin{tabular}{|c|c|c|c|c|}
\hline No & $\begin{array}{c}\text { Aspek Penilaian/ } \\
\text { Kriteria }\end{array}$ & Selalu & $\begin{array}{l}\text { Kadang- } \\
\text { kadang }\end{array}$ & Tidak Pernah \\
\hline $\mathbf{A}$ & Kejujuran & & & \\
\hline 1 & $\begin{array}{l}\text { Setiap hari berkata jujur } \\
\text { kepada orang tua. }\end{array}$ & & & \\
\hline 2 & $\begin{array}{l}\text { Mengembalikan uang } \\
\text { kembalian belanja kepada } \\
\text { orang tua. }\end{array}$ & & & \\
\hline 3 & $\begin{array}{l}\text { Menyerahkan nilai ulangan di } \\
\text { sekolah walaupun nilainya } \\
\text { jelek. }\end{array}$ & & & \\
\hline 4 & $\begin{array}{l}\text { Menyampaikan alasan yang } \\
\text { benar ketika terlambat masuk } \\
\text { kelas. }\end{array}$ & & & \\
\hline B & Kedisiplinan & & & \\
\hline 1 & $\begin{array}{l}\text { Datang ke sekolah tidak } \\
\text { terlambat bahkan lebih awal. }\end{array}$ & & & \\
\hline 2 & Mengerjakan tugas (PR) sesuai & & & \\
\hline
\end{tabular}




\begin{tabular}{|c|l|l|l|l|}
\hline No & \multicolumn{1}{|c|}{$\begin{array}{c}\text { Aspek Penilaian/ } \\
\text { Kriteria }\end{array}$} & Selalu & $\begin{array}{c}\text { Kadang- } \\
\text { kadang }\end{array}$ & Tidak Pernah \\
\hline & dengan yang dijadwalkan. & & & \\
\hline 3 & $\begin{array}{l}\text { Pulang sekolah langsung } \\
\text { bermain dengan teman } \\
\text { sebelum sampai ke rumah. }\end{array}$ & & & \\
\hline 4 & $\begin{array}{l}\text { Mengerjakan ibadah tepat } \\
\text { waktu. }\end{array}$ & & & \\
\hline
\end{tabular}

\section{Catatan:}

Jika siswa memberikan jawaban tidak sesuai dengan kenyataan sehari-hari dari hasil pengamatan guru di sekolah, berarti siswa tersebut tingkat kejujurannya kurang.

Dalam rangka mengetahui tingkat kompetensi guru fiqih Madrasah Tsanawiyah dalam merancang teknik penilaian berbasis kelas, guru-guru fiqih yang berjumlah 30 orang yang berasal dari berbagai kabupaten dan kotamadya di Jawa Barat, dikelompokkan menjadi enam kelompok. Masing-masing kelompok diberi tugas sebagai berikut:

Kelompok A membuat rubrik penilaian produk.

Kelompok B membuat rubrik penilaian unjuk kerja.

Kelompok C membuat rubrik penilaian diri.

Kelompok D membuat rubrik penilaian portofolio.

Kelompok E membuat rubrik penilaian sikap.

Kelompok F membuat rubrik penilaian proyek.

Kelompok yang membuat penilaian tertulis tidak dibentuk, dengan pertimbangan, jenis penilaian ini sudah lazim dilakukan oleh mereka.

Tugas dikerjakan selama 45 menit, kemudian masing-masing kelompok mempresentasikan hasilnya dalm waktu 15 menit. Dalam merancang teknik penilaian berbasis kelas, masing-masing kelompok diharuskan memperhatikan hal-hal di bawah ini:

a. Kesesuaian memilih teknik penilaian dengan kompetensi dasar/indikator pembelajaran.

b. Ketepatan membuat format penilaian.

c. Ketepatan menentukan aspek yang dinilai.

d. Ketepatan menentukan kriteria penilaian.

e. Ketepatan membuat skoring.

f. Ketepatan membuat deskriptor.

Keenam aspek di atas, kemudian digunakan sebagai indikator untuk mengukur tingkat kompetensi guru fiqih Tsanawiyah dalam merancang teknik penilaian berbasis kelas. Keenam indikator tersebut ditransformasikan ke dalam tabel skoring. Berikut adalah tabel skoring penilaian tingkat kompetensi guru fiqih dalam merancang teknik penilaian berbasis kelas. 


\begin{tabular}{|c|c|c|c|c|c|c|c|}
\hline \multirow{2}{*}{ No } & \multirow{2}{*}{ Aspek yang Dinilai } & \multicolumn{5}{|c|}{ SKOR } & \multirow{2}{*}{ KET } \\
\hline & & 1 & 2 & 3 & 4 & 5 & \\
\hline 1 & $\begin{array}{l}\text { Kesesuaian pemilihan teknik } \\
\text { penilaian dengan kompetensi } \\
\text { dasar /indikator }\end{array}$ & & & & & & \\
\hline 2 & $\begin{array}{l}\text { Ketepatan membuat format } \\
\text { penilaian }\end{array}$ & & & & & & \\
\hline 3 & $\begin{array}{l}\text { Ketepatan menentukan aspek } \\
\text { yang dinilai }\end{array}$ & & & & & & \\
\hline 4 & $\begin{array}{l}\text { Ketepatan menentukan kriteria } \\
\text { penilaian }\end{array}$ & & & & & & \\
\hline 5 & Ketepatan membuat skoring & & & & & & \\
\hline 6 & Ketepatan membuat deskriptor & & & & & & \\
\hline
\end{tabular}

Keterangan skor

Skor 1 = sangat tidak mampu

Skor 2 = tidak mampu

Skor 3 = cukup mampu

Skor $4=$ mampu

Skor 5 = sangat mampu

Penjelasan:

a. Kesesuaian pemilihan teknik penilaian dengan kompetensi dasar /indikator:

Skor 1 diberikan apabila kelompok guru fiqih sangat tidak mampu memilih teknik penilaian dengan kompetensi dasar /indikator.

Skor 2 diberikan apabila kelompok guru fiqih tidak mampu memilih teknik penilaian yang sesuai dengan kompetensi dasar /indikator.

Skor 3 diberikan apabila kelompok guru fiqih cukup mampu memilih teknik penilaian yang sesuai dengan kompetensi dasar /indikator.

Skor 4 diberikan apabila kelompok guru fiqih mampu memilih teknik penilaian yang sesuai dengan kompetensi dasar/indikator.

Skor 5 diberikan apabila kelompok guru fiqih sangat mampu memilih teknik penilaian yang sesuai dengan kompetensi dasar/indikator.

b. Ketepatan membuat format penilaian:

Skor 1 diberikan apabila kelompok guru fiqih sangat tidak mampu membuat format penilaian dengan tepat.

Skor 2 diberikan apabila kelompok guru fiqih tidak mampu membuat format penilaian dengan tepat.

Skor 3 diberikan apabila kelompok guru fiqih cukup mampu membuat format penilaian dengan tepat. 
Skor 4 diberikan apabila kelompok guru fiqih mampu membuat format penilaian dengan tepat.

Skor 5 diberikan apabila kelompok guru fiqih sangat mampu membuat format penilaian dengan tepat.

Tahap berikutnya, guru fiqih yang sudah dikelompokan diberi tugas untuk membuat rubrik penilain tertentu, yaitu:

Kelompok A membuat rubrik penilaian produk untuk ketercapaian kompetensi dasar (KD): Menjelaskan ketentuan-ketentuan shadaqah, hibah dan hadiah.

Kelompok B membuat rubrik penilaian diri untuk ketercapaian kompetensi dasar (KD): Menghafal bacaan-bacaan shalat lima waktu

Kelompok $\mathrm{C}$ membuat rubrik penilaian unjuk kerja untuk ketercapaian kompetensi dasar (KD): Mempraktikkan bersuci dari najis dan hadas.

Kelompok D membuat rubrik penilaian portofolio untuk ketercapaian kompetensi dasar (KD): Menjelaskan ketentuan upah.

Kelompok E membuat rubrik penilaian sikap untuk ketercapaian kompetensi dasar (KD):Menjelaskan ketentuan ibadah haji dan umrah.

Kelompok F membuat rubrik penilaian proyek untuk ketercapaian kompetensi dasar (KD): Menjelaskan ketentuan zakat fitrah dan zakat maal.

Tugas membuat rubrik penilaian berdasarkan kompetensi dasar tertentu dikerjakan selama 45 menit. Hasil pekerjaan masing-masing kelompok dituangkan dalam kertas filpcard yang dinilai dan dianalisis. Masing-masing kelompok kemudian mempresentasikan hasil kerja tesebut selama 15 menit.

Kriteria penilaian terhadap hasil kerja kelompok meliputi:

Jika seorang siswa memperoleh skor 25-30, maka ia dapat ditetapkan sangat kompeten.

Jika seorang siswa memperoleh skor 19-24, maka ia dapat ditetapkan kompeten.

Jika seorang siswa memperoleh skor 13 -18, maka ia dapat ditetapkan cukup kompeten.

Jika seorang siswa memperoleh skor kurang dari 7-12, maka ia dapat ditetapkan tidak kompeten.

Jika seorang siswa memperoleh skor kurang 6 dari dapat ditetapkan sangat tidak kompeten.

Setelah keseluruhan hasil karya dan hasil skoring masing-masing kelompok dinilai dan dianalisis, diperoleh data tentang gambaran kompetensi guru Fiqih Madrasah Tsanawiyah dalam merancang penilaian teknik. Data tersebut disajikan dalam tabel sebagai berikut: 
Tabel Kompetensi Guru Fiqh dalam Merancang Penilaian Berbasis Kelas

\begin{tabular}{|c|c|c|c|}
\hline NO & KELOMPOK & SKOR & KRITERIA \\
\hline 1 & A & 22 & Kompeten \\
\hline 2 & B & 26 & Sangat kompeten \\
\hline 3 & $\mathrm{C}$ & 25 & Sangat kompeten \\
\hline 4 & $\mathrm{D}$ & 21 & Kompeten \\
\hline 5 & $\mathrm{E}$ & 26 & Sangat kompeten \\
\hline 6 & $\mathrm{~F}$ & 22 & Kompeten \\
\hline \multicolumn{2}{r|}{ JUTALAH } & 142 & Kompeten \\
\hline
\end{tabular}

Berdasarkan tabel di atas dapat dideskripsikan bahwa guru Fiqih Madrasah Tsanawiyah rata-rata sudah kompeten dalam membuat rancangan penilaian berbasis kelas yang meliputi teknik penilaian produk, portofolio, proyek, unjuk kerja, sikap dan penilaian diri.

\section{SIMPULAN}

Berdasarkan hasil penelitian diketahui bahwa guru mata pelajaran Fiqih di Madrasah Tsanawiyah dalam merancang teknik penilaian berbasis kelas dikategorikan kompeten. Penilaian didasarkan pada hasil karya dan pengamatan proses pembuatan teknik penilai yang meliputi; pembuatan teknik penilaian portofolio, unjuk kerja, proyek, produk, penilaian diri, dan penilaian sikap. Setelah diberikan pemahaman dan sejumlah latihan, Guru Mata Pelajaran Fiqih Madrasah Tsanawiyah se Jawa Barat dapat memahami materi substansi penilaian berbasis kelas dan rata-rata memiliki kemampuan yang "kompeten" dalam merancang teknik tersebut.

Indikasi yang menunjukkan guru Mata Pelajaran Fiqih Madrasah Tsanawiyah mempunyai kompetensi dalam bidang penilaian peserta didik, adalah mereka mampu merancang teknik penilaian berbasis kelas berdasarkan pada aspek dan rumus penilaian yang sudah disepakati bersama.

Setelah guru mendapat pengalaman dan mampu merancang teknik penilaian berbasis kelas, maka guru diharapkan bisa mengaplikasikan di satuan pendidikan masing-masing. Guru juga diharapkan dapat membagi pengalamannya dalam hal merancang teknik penilaian berbasis kelas kepada teman sejawatnya.

\section{DAFTAR PUSTAKA}

Anonimous.2009. Himpunan Perundang-undangan Republik Indonesia tentang: Sistem Pendidikean Nasional (Sisdiknas), Nuansa Aulia. Bandung

Depdiknas, 2002.Kurikulum Berbasis Kompetensi.Jakarta : Pusat Kurikulum Balitbang Depdiknas.

Depdiknas, 2002.Ringkasan Pengelolaan Kurikulum Berbasis Sekolah, Jakarta: Pusat Kurikulum Balitbang Depdiknas 
Forster, Margaret, dan Masters, G. 1996. Porfolios Assessment Resource Kit. Camberwell, Melborne: The Australian Council for Educational Research Ltd.

Forster, Margaret, dan Masters, G. 1998. Product Assessment Resource Kit. Camberwell, Melborne: The Australian Council for Educational Research Ltd.

Forster, Margaret, dan Masters, G. 1999. Paper and Pen Assessment Resource Kit. Camberwell, Melborne: The Australian Council for Educational Research Ltd.

Haryati, Mimin, 2007. Model Dan Teknik Penilaian Pada Tingkat Satuan Pendidikan, Jakarta: Gaung Persada Press.

Muslich, Masnur. 2009. KTSP Pembelajaran Berbasis Kompetensi dan Kontelestual (Panduan bagi Guru, Kepala Sekolah, dan Pengawas Sekolah). PT. Bumi Aksara. Jakarta.

Nitko, Anthony J. 1996. Educational Assessment Of Student. Second Addition, Ohio Merril an imprin of Perentice Hall.

Safari. 2008. Penulisan Butir Soal Berdasarkan Kurikulum Tingkat Satuan Pendidikan (KTSP). Jakarta, ASPI. Departemen Pendidikan Nasional

Sudijono, Anas, 2003. Pengantar Evaluasi Pendidikan. Jakarta : PT. RajaGrafindo Persada.

Thoha, M. Chabib, 2003. Teknik Evaluasi Pendidikan. Jakarta : PT. Raja Grafindo Persada.

Undang Undang RI Nomor 20 Tahun 2003. Tentang Sistem Pendidkan Nasional (SISDIKNAS). Citra Umbara. Bandung.

Worthen, Blaine R and Sanders, James R, 1987. Educational Evaluation. New York \& London: Longman.

http://pakarbisnisonline.blogspot.com/2010/01/kompetensikewirausahaan.html. diunduh tanggal 25 Pebruari 